Original Article

\title{
Resuscitation Fluid Use in a Single Surgical Intensive Care Unit
}

\author{
Yong Dae Lee a, Jeong-Am Ryu a , Dae-Sang Lee a, Jinkyeong Park a, Joongbum Cho a, \\ Chi Ryang Chung a, Yang Hyun Cho b, Jeong Hoon Yang a,c, Gee Young Suh a,d, Chi-Min Park a,e,* \\ a Department of Critical Care Medicine, Samsung Medical Center, Sungkyunkwan University School of Medicine, Seoul, Korea \\ ${ }^{b}$ Department of Thoracic and Cardiovascular Surgery, Samsung Medical Center, Sungkyunkwan University School of Medicine, Seoul, Korea \\ ${ }^{c}$ Division of Cardiology, Department of Medicine, Samsung Medical Center, Sungkyunkwan University School of Medicine, Seoul, Korea \\ ${ }^{d}$ Division of Pulmonary and Critical Care Medicine, Department of Medicine, Samsung Medical Center, Sungkyunkwan University School of Medicine, Seoul, Korea \\ ${ }^{e}$ Department of Surgery, Samsung Medical Center, Sungkyunkwan University School of Medicine, Seoul, Korea
}

\section{Article history:}

Received: March 8, 2019

Revised: June 26, 2019

Accepted: July 12, 2019

\section{*Corresponding Author:}

Departments of Surgery and Critical Care Medicine, Samsung Medical Center, Sungkyunkwan University School of

Medicine, Seoul, Korea

E-mail: dr99.park@samsung.com

\section{ORCID}

Yong Dae Lee

http://orcid.org/0000-0002-3594-9051 Jeong-Am Ryu

http://orcid.org/0000-0003-1705-848X Dae-Sang Lee

http://orcid.org/0000-0002-6448-0125 Jinkyeong Park

http://orcid.org/0000-0002-8833-9062

Joongbum Cho

http://orcid.org/0000-0001-5931-7553

Chi Ryang Chung

http://orcid.org/0000-0003-1830-307X

Yang Hyun Cho

http://orcid.org/0000-0003-1685-3641

Jeong Hoon Yang

http://orcid.org/0000-0001-8138-1367

Gee Young Suh

http://orcid.org/0000-0001-5473-1712

Chi-Min Park

http://orcid.org/0000-0002-8496-3546

\section{ABSTRACT}

Purpose: The aim of this study was to analyze the temporal change of resuscitation fluid use based on all fluids administered in a surgical intensive care unit (ICU).

Methods: The administration of resuscitation fluid to all patients admitted to a surgical ICU of a tertiary referral hospital was investigated from 2008 to 2015. The types and volumes of fluid, and laboratory data taken within 7 days after ICU admission were evaluated. Resuscitation fluids were defined as fluids infused according to stat orders, rather than routine orders.

Results: There were a total of 8,885 admissions to the ICU for 7,886 patients. The volumetric proportion of crystalloid to total resuscitation fluids increased significantly over the study period ( $p<0.001 ; 79.6 \%$ in $2008 ; 93.7 \%$ in 2015 ). Although the proportion of $0.9 \%$ saline to crystalloids decreased, that of balanced solutions increased ( $p<0.001 ; 29.5 \%$ in 2008; $55.6 \%$ in 2015). The use of colloids decreased from $20.4 \%$ in 2008, to 6.3\% in 2015 ( $p<0.001$ ). Proportions calculated using the number of individual fluids administered revealed trends similar to those calculated using volumetric data. The amount of infused $0.9 \%$ saline was weakly correlated with the lowest blood $\mathrm{pH}$ and the highest serum chloride levels ( $\rho=-0.26$ and 0.19 , respectively).

Conclusion: Changes in the trends of fluid resuscitation practice were noted in a single surgical ICU over the 8-year study period. Crystalloid use increased owing to a rise in the utilization of balanced solutions with a downward trend in colloid use.

Keywords: colloids, crystalloid solutions, fluid therapy, intensive care units

\section{Introduction}

Fluid therapy is a common therapeutic intervention in intensive care units (ICU) and has a vital role in the treatment of critically ill patients. There have been studies on which type of fluid, such as crystalloids or colloids, is of benefit to a specific patient in a given clinical context. Evidence suggests that the use of hydroxyethyl starch (HES) may be related to an increased incidence of acute kidney injury (AKI) [1-4], and mortality [4-6] in ICU patients, and that $0.9 \%$ saline containing high chloride may be associated with hyperchloremic metabolic acidosis and AKI [7-9]. In addition, the choice of type and amount of resuscitation fluid may also have an impact on acid-base balance and serum electrolytes [10]. Consequently, the selection of resuscitation fluid can influence clinical outcomes. 
Along with cumulative evidence, some studies revealed that a transition in the pattern of resuscitation fluid administration has taken place in recent years [11,12]. Such studies and guidelines along with physician preferences have probably influenced our clinical practices in fluid resuscitation.

In this study, the temporal change of resuscitation fluid administered was investigated based on all fluids administered in a surgical ICU over the past 8 years, and correlations between the volume of each type of infused fluid and laboratory values of concern were analyzed.

\section{Materials and Methods}

This is a descriptive study on resuscitation fluid administered in a single surgical ICU. The administration of resuscitation fluids to all patients admitted to 1 surgical ICU of a tertiary referral teaching hospital in Seoul, South Korea, from 2008 to 2015 was examined. The surgical ICU is an intensivist-directed ICU with 13 beds managed by an intensivist who specializes in both general surgery and critical care medicine. The intensivist stays in the ICU for more than 10 hours a day and on weekdays. Many evidence-based protocols regarding sepsis, ventilator weaning, sedation, massive transfusion, nutrition, and others are implemented therein. The majority of patients entering the ICU are surgical patients who arrive immediately after elective or non-elective surgery. Patients with postoperative complications or medical problems can also be admitted to the ICU.

The present study protocol was reviewed and approved by the Institutional Review Board of Samsung Medical Center (IRB no.: 2017-10-044-002). The requirements for informed consent were waived by the board.

\section{Resuscitation fluid}

Patient-related data such as clinical characteristics, and the type and amount of fluids administered during the study period were obtained retrospectively from the electronic database of hospital. Resuscitation fluids were defined as fluids infused according to stat orders regardless of infusion rate, except for those given based on routine orders. The purpose of each fluid infusion was not precise because the analysis was performed retrospectively. However, the fluid infused according to stat orders in the ICU represented the resuscitation fluid because almost all the stat orders for fluid infusion would be conducted to replace intravascular volume in the condition where there was a clear intravascular volume deficit.

We retrieved the type and amount of resuscitation fluids, and laboratory data from the time of ICU admission to ICU discharge, or for the first 7 days after ICU admission, whichever was less. Data on administered fluids was acquired by assessing the code number of each prescribed fluid product. The sum of resuscitation fluid volume over the ICU stay for each person was the volume of resuscitation fluid administered to an individual to analyze the trends and laboratory correlations involving resuscitation fluid.

The choice of resuscitation fluid type was left to the discretion of the treating physician or intensivist. The resuscitation fluids were categorized as crystalloids and colloids. Crystalloid solutions consisted of $0.9 \%$ saline (packaging sizes: $250 \mathrm{~mL}, 500 \mathrm{~mL}, 1,000 \mathrm{~mL})$, half saline $(1,000$ $\mathrm{mL})$, Hartmann's solution ( $500 \mathrm{~mL}, 1,000 \mathrm{~mL}$ ), and Plasma Solution A (1,000 mL, CJ Healthcare, Seoul, Korea), which has the same composition as Plasma-Lyte 148. The latter 2 solutions are balanced salt solutions. Crystalloids given in volumes $\leq 100 \mathrm{~mL}$ and dextrose solutions were not counted. Colloids included 5\% human albumin (250 mL, Green Cross, Yongin, Korea) and synthetic colloids [Volulyte 6\%, $500 \mathrm{~mL}$ (Fresenius Kabi, Bad Homburg, Germany), Voluven 6\%, 500 mL (Fresenius Kabi, Bad Homburg, Germany), Hextend 6\%, $500 \mathrm{~mL}$ (CJ Healthcare, Seoul, Korea), and Pentaspan 10\%, 500 $\mathrm{mL}$ (Jeil Pharm, Seoul, Korea)]. Dextran and gelatin were not administered as colloids in this ICU.

To assess the correlations between the volume of each fluid type and laboratory data, the highest values of serum chloride, creatinine, blood urea nitrogen, prothrombin time international normalized ratio (PT INR), and activated partial thromboplastin time were noted, while the lowest values of serum bicarbonate, blood $\mathrm{pH}$, and hemoglobin were taken.

\section{Statistical analysis}

Continuous variables were expressed as the mean \pm standard deviation or median with interquartile range (IQR) as measures of the central tendencies of normally distributed or skewed data, respectively. Categorical variables were represented by counts and proportions. The Jonckheere-Terpstra test was used to examine yearly trends for the volume of each type of infused resuscitation fluid by individual, and the CochranArmitage test was used to analyze yearly trends in the proportions of the total volume of each type of fluid given to all patients over the course of each year. The trend analyses were unadjusted for potential confounding factors such as severity of illness, admission diagnosis, and patient characteristics. Spearman rank correlation coefficients were used to assess the association between the worst laboratory findings and the volumes of infused resuscitation fluid.

All statistical tests were 2-tailed with $p<0.05$ considered statistically significant. Missing values were not imputed unless stated otherwise. Statistical analyses were performed using SAS version 9.4 (SAS Institute, Cary, NC) and R version 3.0.3 (R Foundation for Statistical Computing, Vienna, Austria; http://www.R-project.org). 


\section{Results}

\section{Patients' characteristics}

From 2008 to 2015, there were a total of 8,885 admissions for 7,886 patients to the surgical ICU. The clinical characteristics of the enrolled patients are shown in Table 1. Most of the patients were admitted to the ICU following surgery (scheduled or unscheduled). The median age of all admitted cases was 66 (IQR, 56-73) years, with $99.5 \%$ of patients 16 years of age or older, and approximately 2/3 were male. The median length of stay in the ICU was 23.1 (IQR, 19.0-45.6) hours. Before admission to the ICU, most patients (78.1\%) came directly from the operating room, and this did not differ much through the years. The mean in-hospital mortality rate in the study period was $219 / 8,305$ (2.6\%).

\section{Annual use of resuscitation fluid}

Resuscitation fluids administered in each of the study years are shown in Table 2 . The median total fluid volume by individual, did not typically change from 2009 to 2014 ( $p=0.759$ ), although 2008 and 2015 were the exceptions.

The percentages of the total volumes of each type of resuscitation fluid, over all patients by year are shown in Figure 1. The proportion by volume of crystalloids to total resuscitation fluids increased significantly from $79.6 \%$ in 2008 to $93.7 \%$ in 2015 ( $p<0.001$ ), whereas the proportion by volume of colloids decreased significantly from $20.4 \%$ in 2008 to $6.3 \%$ in 2015 ( $p<0.001)$.

For crystalloid solutions, the volumetric proportion of $0.9 \%$ saline decreased significantly from $64.5 \%$ in 2008 to $42.6 \%$ in 2015 ( $p<0.001$ ), while that of balanced solutions increased

Table 1. Baseline characteristics of the study patients.

\begin{tabular}{|c|c|c|c|c|c|c|c|c|c|}
\hline \multirow{2}{*}{ Characteristic } & \multicolumn{8}{|c|}{ Year } & \multirow{2}{*}{ Total } \\
\hline & 2008 & 2009 & 2010 & 2011 & 2012 & 2013 & 2014 & 2015 & \\
\hline No. of patients & 1,055 & 1,254 & 1,209 & 1,226 & 1,202 & 1,191 & 998 & 750 & 8,885 \\
\hline Male & $\begin{array}{c}688 \\
(65.2)\end{array}$ & $\begin{array}{c}848 \\
(67.6)\end{array}$ & $\begin{array}{c}797 \\
(65.9)\end{array}$ & $\begin{array}{c}803 \\
(65.5)\end{array}$ & $\begin{array}{c}787 \\
(65.5)\end{array}$ & $\begin{array}{c}778 \\
(65.3)\end{array}$ & $\begin{array}{c}666 \\
(66.7)\end{array}$ & $\begin{array}{c}475 \\
(63.3)\end{array}$ & $\begin{array}{l}5,842 \\
(65.8)\end{array}$ \\
\hline $\begin{array}{l}\text { Age (y), } \\
\text { median (IQR) }\end{array}$ & $\begin{array}{c}66 \\
(53-72)\end{array}$ & $\begin{array}{c}65 \\
(54-72)\end{array}$ & $\begin{array}{c}65 \\
(56-72)\end{array}$ & $\begin{array}{c}66 \\
(56-73)\end{array}$ & $\begin{array}{c}65 \\
(55-73)\end{array}$ & $\begin{array}{c}66 \\
(57-74)\end{array}$ & $\begin{array}{c}66 \\
(57-74)\end{array}$ & $\begin{array}{c}68 \\
(59-75)\end{array}$ & $\begin{array}{c}66 \\
(56-73)\end{array}$ \\
\hline $\begin{array}{l}\text { ICU duration (h), } \\
\text { median (IQR) }\end{array}$ & $\begin{array}{c}23.7 \\
(19.0-50.6)\end{array}$ & $\begin{array}{c}23.2 \\
(19.5-45.9)\end{array}$ & $\begin{array}{c}24 \\
(19.7-49.8)\end{array}$ & $\begin{array}{c}23.6 \\
(18.8-48.7)\end{array}$ & $\begin{array}{c}23.2 \\
(19.3-45.7)\end{array}$ & $\begin{array}{c}23 \\
(18.9-41.1)\end{array}$ & $\begin{array}{c}22.3 \\
(18.2-36.7)\end{array}$ & $\begin{array}{c}22.1 \\
(18.5-38.2)\end{array}$ & $\begin{array}{c}23.1 \\
(19.0-45.6)\end{array}$ \\
\hline \multicolumn{10}{|c|}{ Source of ICU admission } \\
\hline $\begin{array}{l}\text { Operating } \\
\text { room }\end{array}$ & $\begin{array}{c}774 \\
(73.4)\end{array}$ & $\begin{array}{l}1,008 \\
(80.4)\end{array}$ & $\begin{array}{c}972 \\
(80.4)\end{array}$ & $\begin{array}{c}975 \\
(79.5)\end{array}$ & $\begin{array}{c}934 \\
(77.7)\end{array}$ & $\begin{array}{c}935 \\
(78.5)\end{array}$ & $\begin{array}{c}744 \\
(74.5)\end{array}$ & $\begin{array}{c}596 \\
(79.5)\end{array}$ & $\begin{array}{l}6,938 \\
(78.1)\end{array}$ \\
\hline General ward & $\begin{array}{c}105 \\
(10.0)\end{array}$ & $\begin{array}{c}89 \\
(7.1)\end{array}$ & $\begin{array}{c}90 \\
(7.4)\end{array}$ & $\begin{array}{c}97 \\
(7.9)\end{array}$ & $\begin{array}{c}123 \\
(10.2)\end{array}$ & $\begin{array}{c}111 \\
(9.3)\end{array}$ & $\begin{array}{c}107 \\
(10.7)\end{array}$ & $\begin{array}{c}69 \\
(9.2)\end{array}$ & $\begin{array}{c}791 \\
(8.9)\end{array}$ \\
\hline $\begin{array}{l}\text { Emergency } \\
\text { room }\end{array}$ & $\begin{array}{c}57 \\
(5.4)\end{array}$ & $\begin{array}{c}47 \\
(3.7)\end{array}$ & $\begin{array}{c}70 \\
(5.8)\end{array}$ & $\begin{array}{c}73 \\
(6.0)\end{array}$ & $\begin{array}{c}74 \\
(6.2)\end{array}$ & $\begin{array}{c}53 \\
(4.5)\end{array}$ & $\begin{array}{c}47 \\
(4.7)\end{array}$ & $\begin{array}{c}27 \\
(3.6)\end{array}$ & $\begin{array}{l}448 \\
(5.0)\end{array}$ \\
\hline Other ICU & $\begin{array}{c}19 \\
(1.8)\end{array}$ & $\begin{array}{c}23 \\
(1.8)\end{array}$ & $\begin{array}{c}23 \\
(1.9)\end{array}$ & $\begin{array}{c}27 \\
(2.2)\end{array}$ & $\begin{array}{c}35 \\
(2.9)\end{array}$ & $\begin{array}{c}39 \\
(3.3)\end{array}$ & $\begin{array}{c}48 \\
(4.8)\end{array}$ & $\begin{array}{c}25 \\
(3.3)\end{array}$ & $\begin{array}{l}239 \\
(2.7)\end{array}$ \\
\hline $\begin{array}{l}\text { Outpatient } \\
\text { department }\end{array}$ & $\begin{array}{c}2 \\
(0.2)\end{array}$ & $\begin{array}{c}1 \\
(0.1)\end{array}$ & $\begin{array}{c}1 \\
(0.1)\end{array}$ & $\begin{array}{c}1 \\
(0.1)\end{array}$ & $\begin{array}{c}2 \\
(0.2)\end{array}$ & $\begin{array}{c}0 \\
(0)\end{array}$ & $\begin{array}{c}0 \\
(0)\end{array}$ & $\begin{array}{c}0 \\
(0)\end{array}$ & $\begin{array}{c}7 \\
(0.1)\end{array}$ \\
\hline Delivery room & $\begin{array}{c}0 \\
(0)\end{array}$ & $\begin{array}{c}0 \\
(0)\end{array}$ & $\begin{array}{c}2 \\
(0.2)\end{array}$ & $\begin{array}{c}0 \\
(0)\end{array}$ & $\begin{array}{c}1 \\
(0.1)\end{array}$ & $\begin{array}{c}0 \\
(0)\end{array}$ & $\begin{array}{c}2 \\
(0.2)\end{array}$ & $\begin{array}{c}1 \\
(0.1)\end{array}$ & $\begin{array}{c}6 \\
(0.1)\end{array}$ \\
\hline Others & $\begin{array}{c}98 \\
(9.3)\end{array}$ & $\begin{array}{c}86 \\
(6.9)\end{array}$ & $\begin{array}{c}51 \\
(4.2)\end{array}$ & $\begin{array}{c}53 \\
(4.3)\end{array}$ & $\begin{array}{c}33 \\
(2.7)\end{array}$ & $\begin{array}{c}53 \\
(4.5)\end{array}$ & $\begin{array}{c}50 \\
(5.0)\end{array}$ & $\begin{array}{c}32 \\
(4.3)\end{array}$ & $\begin{array}{l}456 \\
(5.1)\end{array}$ \\
\hline $\begin{array}{l}\text { In-hospital } \\
\text { mortality* } \\
{[n / \operatorname{total}(n, \%)]}\end{array}$ & $\begin{array}{c}33 / 967 \\
(3.4)\end{array}$ & $\begin{array}{c}23 / 1,185 \\
(1.9)\end{array}$ & $\begin{array}{c}32 / 1,144 \\
(2.8)\end{array}$ & $\begin{array}{c}26 / 1,150 \\
(2.3)\end{array}$ & $\begin{array}{c}25 / 1,119 \\
(2.2)\end{array}$ & $\begin{array}{c}25 / 1,117 \\
(2.2)\end{array}$ & $\begin{array}{c}34 / 929 \\
(3.7)\end{array}$ & $\begin{array}{c}21 / 694 \\
(3.0)\end{array}$ & $\begin{array}{c}219 / 8,305 \\
(2.6)\end{array}$ \\
\hline
\end{tabular}

Data are presented as $n$ (\%) unless otherwise specified.

$\mathrm{ICU}=$ intensive care unit; IQR = interquartile range.

${ }^{*}$ Repeated ICU admissions of a patient during the same hospital stay were counted once. 
Table 2. Resuscitation fluids infused during the study period.

\begin{tabular}{|c|c|c|c|c|c|c|c|c|c|}
\hline \multirow{2}{*}{ Resuscitation fluid } & \multicolumn{8}{|c|}{ Year } & \multirow{2}{*}{ Total } \\
\hline & 2008 & 2009 & 2010 & 2011 & 2012 & 2013 & 2014 & 2015 & \\
\hline $\begin{array}{l}\text { Total fluid } \\
\text { volume (mL) }\end{array}$ & $3,183,750$ & $5,555,500$ & $5,353,500$ & $5,424,500$ & $5,055,000$ & $5,142,000$ & $4,638,750$ & $4,301,750$ & $38,654,750$ \\
\hline Albumin (mL, \%) & $\begin{array}{c}135,250 \\
(4.2)\end{array}$ & $\begin{array}{l}158,000 \\
(2.8)\end{array}$ & $\begin{array}{c}79,000 \\
(1.5)\end{array}$ & $\begin{array}{l}40,000 \\
(0.7)\end{array}$ & $\begin{array}{c}34,750 \\
(0.7)\end{array}$ & $\begin{array}{l}43,750 \\
(0.9)\end{array}$ & $\begin{array}{c}64,250 \\
(1.4)\end{array}$ & $\begin{array}{c}80,000 \\
(1.9)\end{array}$ & $\begin{array}{l}635,000 \\
(1.6)\end{array}$ \\
\hline $\begin{array}{l}\text { Synthetic colloids } \\
\text { (mL, \%) }\end{array}$ & $\begin{array}{c}515,500 \\
(16.2)\end{array}$ & $\begin{array}{c}683,500 \\
(12.3)\end{array}$ & $\begin{array}{c}573,500 \\
(10.7)\end{array}$ & $\begin{array}{c}680,500 \\
(12.5)\end{array}$ & $\begin{array}{c}561,000 \\
(11.1)\end{array}$ & $\begin{array}{l}435,000 \\
(8.5)\end{array}$ & $\begin{array}{l}295,500 \\
(6.4)\end{array}$ & $\begin{array}{c}191,000 \\
(4.4)\end{array}$ & $\begin{array}{l}3,935,500 \\
(10.2)\end{array}$ \\
\hline Half saline (mL, \%) & $\begin{array}{c}152,000 \\
(4.8)\end{array}$ & $\begin{array}{l}276,000 \\
(5.0)\end{array}$ & $\begin{array}{c}166,000 \\
(3.1)\end{array}$ & $\begin{array}{c}100,000 \\
(1.8)\end{array}$ & $\begin{array}{c}271,000 \\
(5.4)\end{array}$ & $\begin{array}{c}215,000 \\
(4.2)\end{array}$ & $\begin{array}{c}137,000 \\
(3.0)\end{array}$ & $\begin{array}{c}74,000 \\
(1.7)\end{array}$ & $\begin{array}{c}1,391,000 \\
(3.6)\end{array}$ \\
\hline $0.9 \%$ saline (mL, \%) & $\begin{array}{c}1,633,500 \\
(51.3)\end{array}$ & $\begin{array}{l}2,659,000 \\
(47.9)\end{array}$ & $\begin{array}{l}2,308,000 \\
(43.1)\end{array}$ & $\begin{array}{l}2,465,500 \\
(45.5)\end{array}$ & $\begin{array}{c}1,882,250 \\
(37.2)\end{array}$ & $\begin{array}{c}2,006,250 \\
(39.0)\end{array}$ & $\begin{array}{c}1,988,500 \\
(42.9)\end{array}$ & $\begin{array}{c}1,717,250 \\
(39.9)\end{array}$ & $\begin{array}{c}16,660,250 \\
(43.1)\end{array}$ \\
\hline $\begin{array}{l}\text { Balanced solutions } \\
(\mathrm{mL}, \%)\end{array}$ & $\begin{array}{c}747,500 \\
(23.5)\end{array}$ & $\begin{array}{c}1,779,000 \\
(32.0)\end{array}$ & $\begin{array}{l}2,227,000 \\
(41.6)\end{array}$ & $\begin{array}{c}2,138,500 \\
(39.4)\end{array}$ & $\begin{array}{l}2,306,000 \\
(45.6)\end{array}$ & $\begin{array}{l}2,442,000 \\
\quad(47.5)\end{array}$ & $\begin{array}{c}2,153,500 \\
(46.4)\end{array}$ & $\begin{array}{l}2,239,500 \\
(52.1)\end{array}$ & $\begin{array}{c}16,033,000 \\
(41.5)\end{array}$ \\
\hline \multicolumn{10}{|l|}{ Total fluid by person } \\
\hline Median (mL, IQR) & $\begin{array}{c}2,500 \\
(1,500- \\
3,500)\end{array}$ & $\begin{array}{c}4,000 \\
(3,000- \\
5,500)\end{array}$ & $\begin{array}{c}4,000 \\
(3,000- \\
5,500)\end{array}$ & $\begin{array}{c}4,500 \\
(3,000- \\
5,500)\end{array}$ & $\begin{array}{c}4,000 \\
(3,000- \\
5,000)\end{array}$ & $\begin{array}{c}4,000 \\
(3,000- \\
5,000)\end{array}$ & $\begin{array}{c}4,500 \\
(3,000- \\
5,500)\end{array}$ & $\begin{array}{c}5,500 \\
(3,937- \\
7,000)\end{array}$ & $\begin{array}{c}4,000 \\
(3,000- \\
5,500)\end{array}$ \\
\hline $\operatorname{Mean} *(m L ; \pm S D)$ & $\begin{array}{c}3,017 \\
( \pm 2,111)\end{array}$ & $\begin{array}{c}4,430 \\
( \pm 2,475)\end{array}$ & $\begin{array}{c}4,428 \\
( \pm 2,271)\end{array}$ & $\begin{array}{c}4,424 \\
( \pm 2,098)\end{array}$ & $\begin{array}{c}4,205 \\
( \pm 2,246)\end{array}$ & $\begin{array}{c}4,317 \\
( \pm 2,610)\end{array}$ & $\begin{array}{c}4,648 \\
( \pm 2,475)\end{array}$ & $\begin{array}{c}5,735 \\
( \pm 2,881)\end{array}$ & $\begin{array}{c}4,350 \\
( \pm 2,464)\end{array}$ \\
\hline
\end{tabular}

$\mathrm{IQR}=$ interquartile range.

*Although total fluid volume per capita is not normally distributed, means are shown for reference.

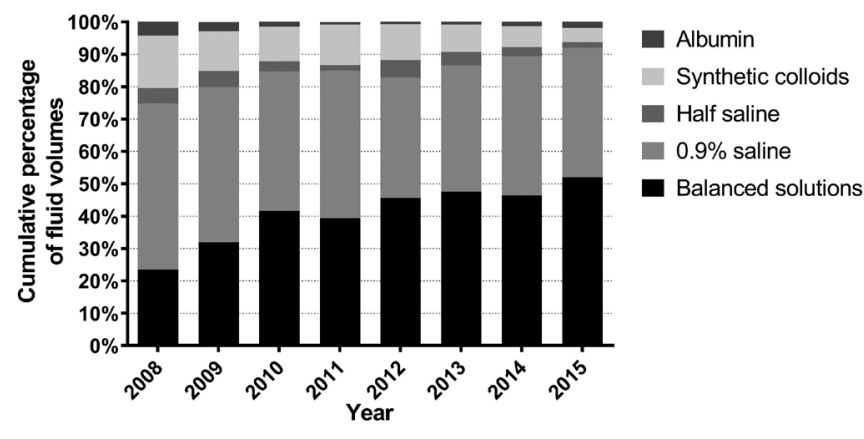

Figure 1. Proportions in volume of each type of resuscitation fluid used by year.

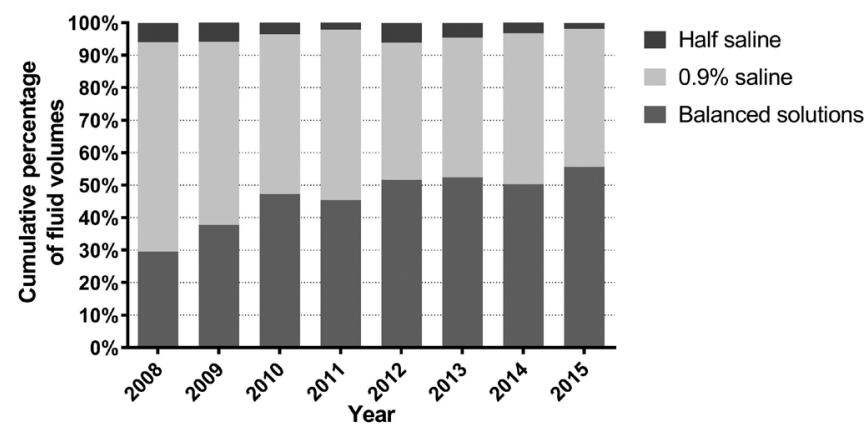

Figure 2. Proportions in volume of each type of crystalloid fluid to total crystalloids.

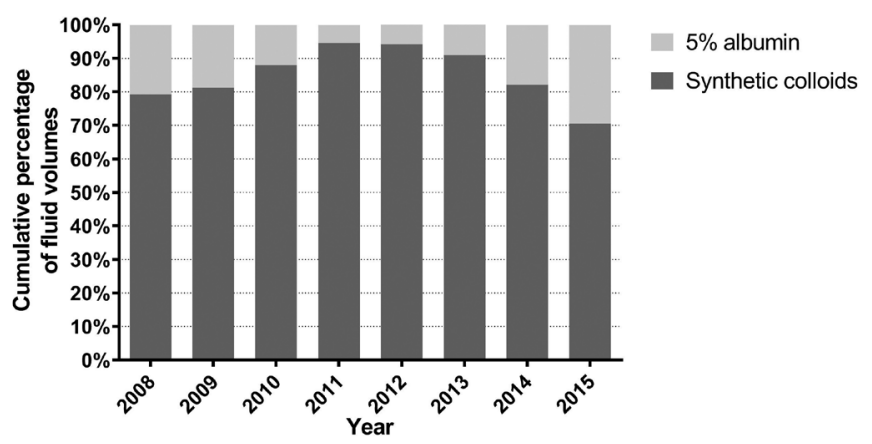

Figure 3. Proportions in volume of each colloid type to total colloids.

from $29.5 \%$ in 2008 to $55.6 \%$ in 2015 ( $p<0.001$; Figure 2 ). With regard to specific colloids, the volumetric proportion of albumin to total colloids decreased from $20.8 \%$ in 2008 to $5.6 \%$ in 2011 , and then increased to $29.5 \%$ in 2015 , whereas that of synthetic colloids to total colloids increased from $79.2 \%$ in 2008 to $94.4 \%$ in 2011, and then decreased to $70.5 \%$ in 2015 (Figure 3). Of synthetic colloids, tetrastarch was the principal HES. 

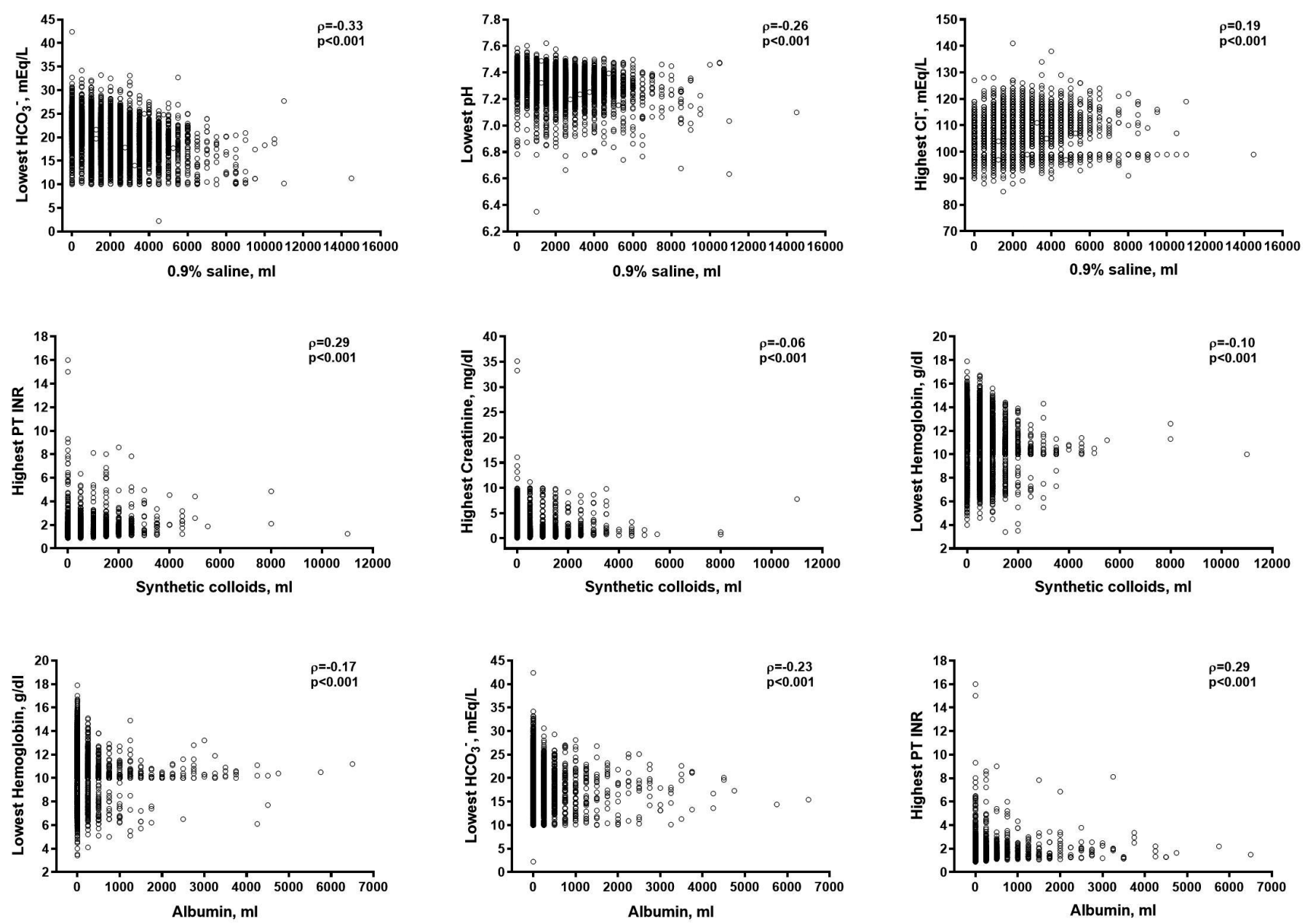

Figure 4. Correlations between resuscitation fluid volume and laboratory values.

Missing values were 3.5\% $(309 / 8,885)$ for blood $\mathrm{pH}, 3.5 \%(309 / 8,885)$ for serum bicarbonate, $0.4 \%(32 / 8,885)$ for serum chloride, $2.0 \%(176 / 8,885)$ for serum creatinine, $4.4 \%(387 / 8,885)$ for PT INR, and $0.3 \%(24 / 8,885)$ for hemoglobin.

PT INR = prothrombin time international normalized ratio.

\section{Correlation between resuscitation fluid and laboratory findings}

Correlations between the volumes of each type of resuscitation fluid and the worst laboratory findings are displayed on scatterplots (Figure 4). The percentage of missing values for laboratory data ranged from $0.3 \%$ to $6.5 \%$. The total volume of $0.9 \%$ saline in individuals infused within the 7-day period after ICU admission, weakly correlated with the lowest blood $\mathrm{pH}$ and serum bicarbonate levels ( $\rho=-0.26$ and -0.33 , respectively), and the highest serum chloride levels ( $\rho=0.19$ ) measured during the same time period, but was not correlated with the highest serum creatinine levels ( $\rho=0.04$ ). The correlation coefficients between the volume of synthetic colloids and the highest PT INR and serum creatinine levels were 0.29 and -0.06 , respectively, and that for the lowest hemoglobin level was -0.10 . The volume of albumin was weakly correlated with the highest PT INR $(\rho=0.29)$ and the lowest hemoglobin and serum bicarbonate levels ( $\rho=-0.17$ and $\rho=-0.23$, respectively).

\section{Discussion}

This study reports the trend changes in fluid resuscitation practice in a single surgical ICU in recent years. We discovered that the patterns of resuscitation fluid utilization had changed during the 8 years from 2008 through 2015 in this surgical ICU. The volumetric proportions of crystalloids to total resuscitation fluids displayed an upward trend and those for colloids displayed a downward trend. The proportion of balanced salt solutions in crystalloids increased, whereas that of $0.9 \%$ saline decreased. Given the downward trends in the administration of both albumin and synthetic colloids, the use of colloids decreased. Proportions of the number of doses of 
each resuscitation fluid administered, showed trends similar to the results of volumetric proportions, although those results are not shown here.

Until a few years ago, colloids were the most used type of resuscitation fluid across the world overall despite variations by geographic location [13]. Starting in 2012, balanced solutions outran $0.9 \%$ saline in resuscitation fluid choice in some areas $[11,12]$ and this overtaking coincides with our findings. Those changes may be influenced by the publication of landmark fluid research $[7-9,14,15]$. There have been clinical trials and meta-analyses over the past decade comparing each type of fluid. In view of resuscitation studies regarding albumin versus crystalloid preparations, albumin was as effective as crystalloid in critically ill patients $[16,17]$ and may be associated with lower mortality in those with severe sepsis [18], in contrast to increased mortality in traumatic brain injury patients [19]. Studies comparing HES with crystalloid fluid reported that HES increased the risk of AKI and renal replacement therapy (RRT) $[2,4]$ and death [4-6] in ICU patients, and was also associated with coagulopathy and a greater need for blood transfusion [20]. The use of colloid was continuously reduced following consistent results of these high-quality studies and metaanalyses $[2,4,5,12,15]$. Furthermore, Surviving Sepsis Campaign (SSC) guidelines in 2008 recommended that crystalloids or colloids be both used in resuscitation fluids in patients with severe sepsis and septic shock [21]. However, the guidelines changed the recommendation so that crystalloid fluid, not HES, could be used as the initial fluid of choice with albumin use in cases of substantial fluid administration in the 2012 guidelines [22].

Of the crystalloid solutions, $0.9 \%$ saline is known to be more likely to increase AKI and RRT [7-9] and mortality [14,15] in critically ill patients compared with balanced salt solutions, although a more recent randomized clinical trial showed no difference in the risk of AKI in patients given balanced crystalloids and $0.9 \%$ saline [23]. Figure 5 shows trends in resuscitation fluid use during the study period and relevant previous studies in chronological order. An international cross-

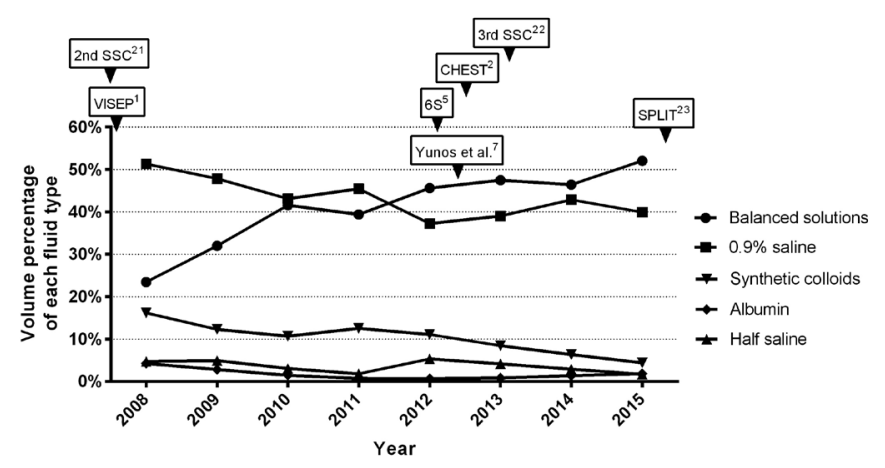

Figure 5. Trend of resuscitation fluid use from 2008 to 2015 and relevant studies. sectional study revealed that geographic setting, availability, and cost were important predictors of fluid selection, with severity of illness uninfluential in fluid choice [13]. Besides these factors, concerns about adverse outcomes, including AKI and mortality, possibly caused by an inappropriate choice of fluid were most likely to influence the fluid ordering practices of ICU physicians in our surgical ICU.

Although it was nearly impossible to evaluate the relationship between the fluid choice and clinical outcome in this study because of the study design and numerous confounding factors, we tried to analyze the correlation between fluid infusion and laboratory findings. In each patient, the total volume of $0.9 \%$ saline and synthetic colloids administered was weakly correlated with the worst findings for the values of blood pH, serum bicarbonate, serum chloride, and PT INR, and negligibly correlated with those of serum creatinine. The albumin volume weakly correlated with hemoglobin levels, serum bicarbonate, and PT INR. It appears that albumin was preferred for patients in more critical condition, such as those with septic shock, anemia, acidosis, and coagulopathy. The number of laboratory tests performed, and the amount of time that elapsed between blood sampling and fluid infusion, were not evaluated. Therefore, we believe there is a weak correlation between infused fluid volume and laboratory values. The effect of resuscitation fluids on intravascular volume expansion differs among colloid products as well as between crystalloids and colloids, and the number or volume of infused fluids alone is insufficient to compare resuscitation effects between fluid types.

Although we did not control for potential confounders, unexpectedly, our results revealed that there was no decreasing trend in the whole fluid volume per capita; the year 2008 was not taken into account because an open ICU model was employed that year, and 2015 was omitted owing to an outbreak of Middle East Respiratory Syndrome in South Korea. This finding is inconsistent with the restrictive strategy on fluid resuscitation, which is implemented based on the recognition that positive fluid balance may be associated with increased mortality in critically ill patients [24,25], including those with sepsis [26], and acute lung injury [27,28]. This discrepancy would be caused by the different characteristics of surgical ICU where there are a lower population of acute lung injuries and a higher number of patients with hypovolemic shock or intraoperative volume loss rather than general ICU.

There were several limitations to the present study. Firstly, this is a single-center retrospective study. Our results may not be applicable to non-intensivist-directed or non-academic ICU settings where staff may be less likely to keep up with recent findings and current thinking. Secondly, confounding variables, such as diagnosis on admission, type of surgery, severity of illness, and comorbidities were not identified or controlled 
for. Thirdly, our definition of resuscitation fluid during 7 days in the ICU was somewhat arbitrary; it did not include blood products and the infusion rate was not taken into account. Although there could be many inevitable biases and the definition of resuscitation fluid was arbitrary in this study, we assessed the trends in resuscitation fluid administered based on both counts and amounts of all fluids administered to every patient admitted to the surgical ICU over the course of 8 years, unlike prior studies of resuscitation fluids, most of which were carried out through a survey given to ICU physicians and/or over a short time period of 24 hours.

This study described the in-practice patterns of resuscitation fluid in an academic surgical ICU in South Korea. We consider that changes in fluid use would be primarily due to a growing body of knowledge about each type of fluid. In conclusion, trend changes in fluid resuscitation practice were observed in a single surgical ICU over the 8-year study period. Crystalloid use increased owing to a rise in the utilization of balanced salt solutions, whereas colloid use was observed to be on a downturn.

\section{Conflicts of Interest}

No potential conflict of interest relevant to this article was reported.

\section{Disclosure}

These results were presented in a poster session at the 46th Annual Congress of Society of Critical Care Medicine, Honolulu, Hawaii, January 2017.

\section{References}

[1] Brunkhorst FM, Engel C, Bloos F, Meier-Hellmann A, Ragaller M, Weiler $\mathrm{N}$, et al. Intensive insulin therapy and pentastarch resuscitation in severe sepsis. N Engl J Med 2008;358(2):125-39.

[2] Myburgh JA, Finfer S, Bellomo R, Billot L, Cass A, Gattas D, et al. Hydroxyethyl starch or saline for fluid resuscitation in intensive care. $\mathrm{N}$ Engl J Med 2012;367(20):1901-11.

[3] Mutter TC, Ruth CA, Dart AB. Hydroxyethyl starch (HES) versus other fluid therapies: Effects on kidney function. Cochrane Database Syst Rev 2013;(7):CD007594.

[4] Zarychanski R, Abou-Setta AM, Turgeon AF, Houston BL, McIntyre L, Marshall JC, et al. Association of hydroxyethyl starch administration with mortality and acute kidney injury in critically ill patients requiring volume resuscitation: A systematic review and meta-analysis. JAMA 2013;309(7):678-88.

[5] Perner A, Haase N, Guttormsen AB, Tenhunen J, Klemenzson G, Aneman A, et al. Hydroxyethyl starch 130/0.42 versus Ringer's acetate in severe sepsis. N Engl J Med 2012;367(2):124-34.

[6] Perel P, Roberts I, Ker K. Colloids versus crystalloids for fluid resuscitation in critically ill patients. Cochrane Database Syst Rev 2013;(2):CD000567.
[7] Yunos NM, Bellomo R, Hegarty C, Story D, Ho L, Bailey M. Association between a chloride-liberal vs chloride-restrictive intravenous fluid administration strategy and kidney injury in critically ill adults. JAMA 2012;308(15):1566-72.

[8] Yunos NM, Bellomo R, Glassford N, Sutcliffe H, Lam Q, Bailey M. Chlorideliberal vs. chloride-restrictive intravenous fluid administration and acute kidney injury: An extended analysis. Intensive Care Med 2015;41(2):25764.

[9] Shaw AD, Bagshaw SM, Goldstein SL, Scherer LA, Duan M, Schermer CR, et al. Major complications, mortality, and resource utilization after open abdominal surgery: 0.9\% saline compared to Plasma-Lyte. Ann Surg 2012;255(5):821-9.

[10] Bellomo R, Morimatsu H, French C, Cole L, Story D, Uchino S, et al. The effects of saline or albumin resuscitation on acid-base status and serum electrolytes. Crit Care Med 2006;34(12):2891-7.

[11] Hammond NE, Taylor C, Saxena M, Liu B, Finfer S, Glass P, et al. Resuscitation fluid use in Australian and New Zealand Intensive Care Units between 2007 and 2013. Intensive Care Med 2015;41(9):1611-9.

[12] Miller TE, Bunke M, Nisbet P, Brudney CS. Fluid resuscitation practice patterns in intensive care units of the USA: A cross-sectional survey of critical care physicians. Perioper Med (Lond) 2016;5:15.

[13] Finfer S, Liu B, Taylor C, Bellomo R, Billot L, Cook D, et al. Resuscitation fluid use in critically ill adults: An international cross-sectional study in 391 intensive care units. Crit Care 2010;14(5):R185.

[14] Raghunathan K, Shaw A, Nathanson B, Sturmer T, Brookhart A, Stefan MS, et al. Association Between the Choice of IV Crystalloid and InHospital Mortality Among Critically Ill Adults with Sepsis. Crit Care Med 2014;42(7):1585-91.

[15] Rochwerg B, Alhazzani W, Sindi A, Heels-Ansdell D, Thabane L, FoxRobichaud A, et al. Fluid resuscitation in sepsis: A systematic review and network meta-analysis. Ann Intern Med 2014;161(5):347-55.

[16] Finfer S, Bellomo R, Boyce N, French J, Myburgh J, Norton R; SAFE Study Investigators. A comparison of albumin and saline for fluid resuscitation in the intensive care unit. N Engl J Med 2004;350(22):2247-56.

[17] Caironi P, Tognoni G, Masson S, Fumagalli R, Pesenti A, Romero M, et al. Albumin replacement in patients with severe sepsis or septic shock. N Engl J Med 2014;370(15):1412-21.

[18] SAFE Study Investigators. Impact of albumin compared to saline on organ function and mortality of patients with severe sepsis. Intensive Care Med 2011;37(1):86-96

[19] SAFE Study Investigators. Saline or albumin for fluid resuscitation in patients with traumatic brain injury. N Engl J Med 2007;357(9):874-84.

[20] Lira A, Pinsky MR. Choices in fluid type and volume during resuscitation: Impact on patient outcomes. Ann Intensive Care 2014;4:38.

[21] Dellinger RP, Levy MM, Carlet JM, Bion J, Parker MM, Jaeschke R, et al. Surviving Sepsis Campaign: International guidelines for management of severe sepsis and septic shock: 2008. Intensive Care Med 2008;34(1):1760.

[22] Dellinger RP, Levy MM, Rhodes A, Annane D, Gerlach H, Opal SM, et al. Surviving Sepsis Campaign: international guidelines for management of severe sepsis and septic shock: 2012. Crit Care Med 2013;41(2):580-637.

[23] Young P, Bailey M, Beasley R, Henderson S, Mackle D, McArthur C, et al. Effect of a Buffered Crystalloid Solution vs Saline on Acute Kidney Injury Among Patients in the Intensive Care Unit: The SPLIT Randomized Clinical Trial. JAMA 2015;314(16):1701-10.

[24] Lee J, de Louw E, Niemi M, Nelson R, Mark RG, Celi LA, et al. Association between fluid balance and survival in critically ill patients. J Intern Med 2015;277(4):468-77.

[25] Barmparas G, Liou D, Lee D, Fierro N, Bloom M, Ley E, et al. Impact of positive fluid balance on critically ill surgical patients: A prospective observational study. J Crit Care 2014;29(6):936-41.

[26] Vincent JL, Sakr Y, Sprung CL, Ranieri VM, Reinhart K, Gerlach H, et al. Sepsis in European intensive care units: Results of the SOAP study. Crit Care Med 2006;34(2):344-53.

[27] National Heart, Lung, and Blood Institute Acute Respiratory Distress Syndrome (ARDS) Clinical Trials Network, Wiedemann HP, Wheeler AP, Bernard GR, Thompson BT, Hayden D, et al. Comparison of two fluid-management strategies in acute lung injury. N Engl J Med 2006;354(24):2564-75.

[28] Rosenberg AL, Dechert RE, Park PK, Bartlett RH; NIH NHLBI ARDS Network. Review of a large clinical series: Association of cumulative fluid balance on outcome in acute lung injury: A retrospective review of the ARDS net tidal volume study cohort. J Intensive Care Med 2009;24(1):3546. 